investigations carried out at the National Physical Laboratory or at the Chemical Research Laboratory, by the Forest Products Research Station, the Fuel Research Station, the Lubrication Research Board, in metallurgical matters, furnace design, aircraft design and other fields which have yielded equally significant results for industry or the general advantage of the community. A final reference can only be made to the discovery in radio research, which is one of the most interesting of the year, of the existence of three new electrified regions in the atmosphere between 4 and 40 miles above the earth. These regions are thus well below the well-known Heaviside and Appleton regions, which play such an important part in broadcasting to great distances and in making Empire com. munication on short waves possible.

Enough has been said, however, to demonstrate the value of the work of the Department alike in the latest fields of scientific activity and investigation and in the very oldest on which industrial prosperity and civic welfare alike depend. No doeument could in fact be better calculated to show the contribution which scientific research can make to human welfare and progress if it is applied to constructive and social ends, and not prostituted for destructive purposes as in preparations for war.

\title{
Boron and the Control of Plant Disease
}

\section{By Dr. Winifred E. Brenchley}

$\mathrm{T}^{\mathrm{n}}$ HE value of boron in improving plant growth was indicated in the early part of this century by various workers, notably Agulhon ${ }^{1}$, but it was not until 1923 that its essential nature was definitely proved by Warington ${ }^{2}$ in her work on the broad bean. Since then, research workers and practical men have taken up the matter all over the world, and various obscure physiological diseases of crops have been traced to a deficiency of boron in the soil. Crown rot of sugar beet, raan in swedes, topsiekte of tobacco and certain leafroll diseases of potato all respond favourably to the application of small dressings of borax, usually ranging from $10 \mathrm{lb}$. to $20 \mathrm{lb}$. per acre for these relatively short-lived plants. Heavy dressings of boron compounds are unfavourable as they produce toxic symptoms which may cause grave damage.

During the last few years, active experimental work has been carried out in widely separated centres on the control of cork disease, corky core, or internal cork of apples, all apparently representing the same trouble. The surface of the fruit becomes uneven, and brown areas of diseased tissue are distributed throughout the apple, particularly around the core, greatly reducing the market value of the crop.

Acting on a suspicion that the disease was due to the deficiency of some essential element, McLartys tested thirty chemicals by injecting them into the trunks of affected trees. Of these, boric acid and manganese borate proved effective in controlling corky core, as with injections above a minimum of $1.83 \mathrm{gm}$. per $100 \mathrm{sq}$. $\mathrm{cm}$. of the cross-sectional area of the trunks no disease occurred, and the total crop was greatly increased.
Heavier doses up to $5.92 \mathrm{gm}$. did not cause any damage to the foliage, though there was slight injury to the bark and cambium at the point of injection. In these experiments the test material was nearly always packed into the trunks in the dry form, because of the greater convenience in handling and also because larger amounts could be used without injury to the foliage.

At the same time, Askew and his collaborators in New Zealand ${ }^{4}$ and Jamalainen ${ }^{5}$ in Finland were also investigating the problem. In New Zealand boron again proved to be the effective controlling agent out of a large number of elements tested, and the method of getting it into the tree seems to be largely a matter of convenience. Borax spread broadcast at the rate of $\frac{1}{2}-1 \mathrm{lb}$. per tree or $50-100 \mathrm{lb}$. per acre rapidly penetrates the soil to the absorbing zone of the roots in a favourably moist season, and is taken up and passed into the leaves and fruit, giving good control of internal cork. The penetration might not be so good or rapid in a dry season, but there is a considerable safety margin, as the normal annual requirement per acre for leaf and fruit growth has been found by analysis to be only about $14 \mathrm{oz}$. of borax. Injections of solution containing 0.25 per cent of hydrated borax were equally effective in increasing the boron content of leaves and fruit, and internal cork was prevented by so little as $2.5 \mathrm{gm}$. borax per tree. Where the injections were made into a branch, a certain amount of migration of boron took place into untreated branches, even when the point of injection was some way above the crotch. Similar control was obtained by applying borax sprays at the rate of one gallon per tree, and the suggestion is made that two applications 
of a 0.25 per cent solution in spring at an interval of three weeks would prove useful in commercial practice.

In the Finnish experiments ${ }^{5}$, boric acid was used as well as borax, and smaller quantities were also tested and proved effective in the control of cork disease. This may be due to a combination of factors, including the type of soil, the different climatic conditions and the fact that the boron compound was watered into the soil. The size of the trees is not indicated, and it is possible that the Finnish trees were younger and smaller than those in New Zealand and so responded to a lower dressing.

Boron deficiency not only damages the tissue of the fruit but also affects the chemical composition, as Jamalainen found that diseased apples contain more glucose and fructose than saccharose, and that the carbohydrates of the actual diseased tissues remain in the starch stage and are not converted. The striking similarity in the results obtained in different parts of the world afford conclusive proof of the value of boron in the control of corky core in apples, and gives rise to the hope that other obscure diseases of fruit trees may also prove to be due to deficiency of some essential minor element, which can be supplied at a relatively low cost and without undue difficulty.

\footnotetext{
1 Agulhon, H., "Recherches sur la présence et le rôle du bore chez les végetaux", Thèse, Paris (1910).

'Warington, K., "The Effect of Boric Acid on the Broad Bean and certain other Plants", Ann. Bot., 37, 629-72 (1923).

"Mclarty, H. R., "Tree Injections with Boron and other Materials as a Control for Drought spot and Corky Core of Apple", Sci. Agric., 16, 12, 625 (Aug. 1936).

'Askew, H. O., Chittenden, E., Thomson, R. H. K., and Atkinson, J. D., "The Use of Borax in the Control of 'Internal Cork' of Apples" New Zealand J. Sci. Tech., 18, 365 (1936).

S.Jamalainen, E. A., "On Cork Disease of the Apple and on its Appearance in Finjand", J. Sci. Agric. Soc. Finland, 8, 24-35 (1936). "The Effect of Boron on the Occurrence of Cork Disease in Apples", Agric. Expt. Activities of the State, Pub. 89, pp. 11 (1936) (English summaries).
}

\section{Obituary Notices}

Mr. William Taylor, O.B.E., F.R.S.

$\mathrm{W}^{\mathrm{u}}$ ILLIAM TAYLOR, who died at the age of seventy-one years on February 27, showed a bent towards engineering early in life, making his own lathe at an age when most children are playing with toys. He learnt from the village blacksmith and the local wheelwright. His first schoolmaster was Dr. Richard Wormald of London, a pioneer in the teaching of science, at whose lectures he assisted as demonstrator. The school was so far advanced in its methods as to have a workshop for metal and wood work. At this time, William and his brother made in their workshop at home, which they had themselves built, a pair of the first telephones ever made in England, and one of the first copies of Edison's recently invented tinfoil phonograph. Later, William Taylor was one of the first students at the Finsbury Technical College, his teachers being Profs. H. E. Armstrong, Ayrton and Perry. He made for Ayrton and Perry the model of their ammeter which is now in the Science Museum. Some of the instruments made in his student days are still in use at the factory he started in conjunction with his brother. The firm thus founded in 1886 was known at first as T. S. and W. Taylor, and afterwards as Taylor, Taylor and Hobson. The founders had the unusual experience of celebrating last year the jubilee of the business they had established.

The firm started by manufacturing photographic lenses, and William Taylor soon saw that accurate lens manufacture depended on accurate screws, so he invented methods of measuring the essential dimensions of screws with a micrometer, using cylinders placed between the threads; he then found it necessary to make his own screw-cutting lathes to produce threads of the necessary accuracy. He also invented the abrupt thread to facilitate the engagement of the lens in its flange. The Royal Photographic Society had proposed standard flange screws, but at first the manufacturers were antagonistic and the Taylor firm was the only one with the necessary equipment to conform to these standards. This experience in exact workmanship was invaluable in the manufacture of the anastigmat, when, in consequence of the reputation of the brothers, they were offered the manufacture of the Cooke lens, the first anastigmat of English design. The inventor of this lens, H. Dennis Taylor, was not related to William Taylor.

In the manufacture of photographic lenses, the need was felt for speedier and neater methods of engraving the mounts than was possible by hand; this led to the design of the engraving machine which, originally intended only for use in Taylor's own works, quickly found a market outside and greatly enhanced the reputation of the firm.

William Taylor next turned his attention to im. proving the methods of glass working, and practically revolutionized the process of making lenses, so that it became possible to manufacture them in quantity and of high quality. Machines were made for sawing the glass, cutting out disks, roughing to shape, smoothing and polishing, and finally edging. In the design of the automatic grinder, Taylor's work was fundamental. The iron tool fed with loose abrasive, as previously used, quickly lost its shape. He saw that by using a cup-shaped abrasive wheel-he secured one of the first to arrive in Great Britain-any curvature could be produced on the glass by varying the angle between the axes of the revolving work 